\title{
Co-Precipitation Procedure Using Copper (II) Methylbutyldithiocarbamate for Atomic Absorption Spectrophotometric Determination of Heavy Metals in Aqueous Standard Solutions and Environmental Samples
}

Ayodele Rotimi Ipeaiyeda* and Olayinka Jumoke Asagunla

Department of Chemistry, University of Ibadan, Ibadan, Nigeria

\begin{abstract}
Co-precipitation technique using copper (II) methylbutyldithiocarbamate prior to Nickel (II), manganese (II), cobalt (II), lead (II) and chromium (III) determinations their aqueous standard solutions by spectrophotometric method was developed in this study. The effect of $\mathrm{pH}$, sample volume, amounts of methylbutyldithiocarbamate and copper (II) on the recovery of metal ions were studied. The heavy metals in the precipitate were determined by Flame Atomic Absorption Spectrophotometry (FAAS). The detection limits for the determination ranged from $0.003 \mathrm{mg} / \mathrm{L}$ to $0.006 \mathrm{mg} / \mathrm{L}$. The coprecipitation procedure was applied for spectrophotometric determination of the heavy metals in water and sediment samples from River Ufara in Igbokoda of Ondo State, part of Nigeria where oil companies were at a time already operating. The mean concentration (ppm) of $\mathrm{Ni}, \mathrm{Mn}, \mathrm{Co}, \mathrm{Pb}$ and $\mathrm{Cr}$ were $11.7 \pm 5.5$ and $13.2 \pm 1.1 ; 18.7 \pm 4.2$ and $63.4 \pm 18.2 ; 1.52 \pm 0.11$ and $5.60 \pm 1.30 ; 7.8 \pm 1.5$ and $21.9 \pm 3.2 ; 6.06 \pm 0.80$ and $19.5 \pm 0.9$ for water and sediment samples respectively. The mean concentrations of these metals for samples from this area were significantly different from corresponding concentrations for control samples which signified an evidence of metal pollution attributed to oil relating activities. There was also no significant difference in the concentrations of metals in samples using spectrometric technique with co-precipitation procedure and without co-precipitation procedure.
\end{abstract}

Keywords: Co-precipitation; Methylbutyldithiocarbamate; Wastewater samples; Heavy metals; Spectrophotometry

\section{Introduction}

The world is grappling with enormous and unprecedented environmental crises. These include massive destruction of natural water bodies such as rivers and streams at an alarming rate resulting in tremendous increase in water contamination and accumulation of contaminants in sediments beyond the levels that can be self-purified by the hydrosphere nor assimilated by aquatic organisms. Nearly every government around the world advocates for river water free from harmful contaminants for their citizens who rely absolutely on such type of water for drinking and domestic purposes. One of such contaminants includes heavy metals [1,2]. There has been increased concern regarding deleterious effects of heavy metals such as lead, cadmium, mercury, nickel, copper, and zinc as contaminants in rivers and sediments. Fish caught in rivers with elevated levels of these metals such as mercury resulted to a high incidence of mental retardation, seizure and pyramidal signs [3-6]. Outbreak of health disorder had been linked with the use of heavy metals contaminated rivers for drinking and cooking $[7,8]$. Also, sediment contamination poses one of the worst environmental problems in marine ecosystem $[9,10]$. These incidences could clearly be as a consequence of the effect of either contaminated run off from agricultural field, disposal of sewage and industrial wastes or heavy ship traffic [11]. The serious adverse effects of water pollution by toxic heavy metals on humans and wildlife especially in Bangladesh and West Bengal in India [12] and California in the United State [13] had been reported. Some other prominent studies done on the heavy metal contamination of water environment traceable to industrial, agricultural, urban, mining and smelting activities had been documented in the literatures [14-18]. Heavy metals in water quality assessment are usually determined by atomic absorption spectrometry (AAS) with flame or graphite furnace and atomic emission-inductively coupled plasma (ICP) spectrometry, after acid digestion of the samples. Anodic stripping voltametry (ASV) and other electrochemical techniques such as polarography have been used for some the metals.
Spectrophotometric methods based on colour development after addition of specific reagents have also been used. Conventional atomic absorption spectrometry is suitable for most metals. However, for some metals such as $\mathrm{Hg}$, As and Se which are not of interest in this study, the method has to be modified. Cold vapour flameless AAS is generally used for $\mathrm{Hg}$ while hydride generation has been used for As and Se. Also, some interfering effects in the determination of heavy metals especially chromium by AAS has been reported [19]. Hexavalent chromium can be easily reduced to the trivalent state in polluted waters from anoxic environments. So, the determination of such metal in water sample might require the application of preconcentration technique. Chelate extraction is one of the preconcentration techniques most frequently described in the literatures. Therefore, a simple, rapid, reliable and non-expensive analytical method commonly employed for the determination of these heavy metals in environmental samples is Flame Atomic Absorption Spectrophotometry (FAAS) [20-23]. This method is highly selective but less sensitive compared with other spectra methods such as inductively coupled plasma - mass spectrometry (ICP-MS), inductively coupled plasma - atomic emission spectrometry (ICP-AES) and graphite furnace - atomic absorption spectrometry (GF-AAS) which are costlier [24]. Thus, coprecipitative preconcentration procedure prior to FAAS determination of heavy

*Corresponding author: Ayodele Rotimi Ipeaiyeda, Department of Chemistry, University of Ibadan, Ibadan, Nigeria, Tel: +23480339484; E-mail: ayosade2003@ yahoo.com

Received November 26, 2014; Accepted December 19, 2014; Published December 22, 2014

Citation: Ipeaiyeda AR, Asagunla OJ (2014) Co-Precipitation Procedure Using Copper (II) Methylbutyldithiocarbamate for Atomic Absorption Spectrophotometric Determination of Heavy Metals in Aqueous Standard Solutions and Environmental Samples. J Environ Anal Toxicol 4: 257. doi: 10.4172/2161-0525.1000257

Copyright: (c) 2014 Ipeaiyeda AR, et al. This is an open-access article distributed under the terms of the Creative Commons Attribution License, which permits unrestricted use, distribution, and reproduction in any medium, provided the original author and source are credited. 
Citation: Ipeaiyeda AR, Asagunla OJ (2014) Co-Precipitation Procedure Using Copper (II) Methylbutyldithiocarbamate for Atomic Absorption Spectrophotometric Determination of Heavy Metals in Aqueous Standard Solutions and Environmental Samples. J Environ Anal Toxicol 4: 257. doi: $10.4172 / 2161-0525.1000257$

Page 2 of 7

method is often employed. The procedure is efficient and has come to the forefront in view of the several advantages if offers. These include the fact that the technique is simple, fast and several metal ions can be preconcentrated and separated from sample matrix simultaneously [20]. Coprecipitation by dithiocarbamate (as an organic chelating agent) of various metal ions from environmental samples such as rivers and sediments has been reported: dibenzyldithiocarbamate [25], 4-methylpiperidinedithiocarbamate [26], pyrrolidinedithiocarbamate [27] and cyclo-hexylmethyldithiocarbamate [28]. Dithiocarbamate is a strong chelating and co-precipitating agents for heavy metals due to the presence of sulfur donor atoms in its structure. Using dithiocarbamate as a chelating agent, a precipitate is formed by the combination of a carrier element such as copper, nickel, aluminium and magnesium which have been used for preconcentration studies [29,30]. Based on our literature search, this is the first time methlybutyldithiocarbamate is utilized for the coprecipitation procedure prior to FAAS determination of metal ions. In this study, copper was employed as a carrier element and methylbutyldithiocarbamate as chelating agent to establish a coprecipitation procedure for $\mathrm{Ni}$ (II), $\mathrm{Co}$ (II), $\mathrm{Cr}$ (III), $\mathrm{Mn}$ (II) and $\mathrm{Pb}$ (II) prior to their determination by FAAS. The procedure was applied to the determination of these metal ions in water and sediments samples from River Ufara of Igbokada of Ondo state, Nigeria.

\section{Experimental Analysis}

\section{Instruments}

Heavy metals concentrations were measured with a Perkin Elmer AAnalyst 200 (Massachusetts, USA) Atomic Absorption Spectrophotometer with deuterium background corrector. This instrument with slit range of $1.8-2.7 \mathrm{~mm}$ was equipped with a hollow cathode lamp and operated in the air-acetylene flame mode. The lamps for the heavy metals were operated at standard wavelengths specified in the manufacturer's manual. A pH meter, Jenway 3520 model glasselectrode was utilized for measuring $\mathrm{pH}$ values of the buffer and other aqueous solutions. Hitachi - High Speed Refrigerated Centrifuges (Himac CR21GII) was used to centrifuge all solutions.

\section{Preparation of reagents and solutions}

Analytical grade reagents of high purity from Sigma (St Louis, MO, USA) were used for preparation of stock standard solutions. Working standard solutions were obtained by appropriate dilution with de-ionized distilled water which was equally used throughout the experimental work. A $1 \%(\mathrm{w} / \mathrm{v})$ solution of sodium methylbutyldithiocarbamate $\left[\mathrm{Na}\left(\mathrm{R}_{1} \mathrm{R}_{2} \mathrm{dtc}\right)\right]$ was prepared by dissolving $1.0 \mathrm{~g}$ of the salt in little ethanol, then made up to $100 \mathrm{~mL}$ with deionized distilled water. $\mathrm{R}_{1} \mathrm{R}_{2}$ and dtc represent methylbutyl and dithiocarbbamate respectively. $31 \mathrm{~mL}(0.52 \mathrm{~mol})$ of carbon disulphide and $40 \mathrm{~mL}$ of $50 \%$ aqueous solution of sodium hydroxide were added to a stirring solution of $0.5 \mathrm{~mol}$ disubstituted amine, $\mathrm{R}_{1} \mathrm{R}_{2} \mathrm{NH}$, in $50 \mathrm{~mL}$ ethanol at below $4^{\circ} \mathrm{C}$. After about 5 hours of stirring, the ligand formed was recrystallized from the solution of ethanol and dried over silica gel in a desiccator.

In the preparation of copper (II) methylbutyldithiocarbamate, an aqueous solution of sodium salt of methylbutyldithiocarbamate ligand (0.01 mol) was added in drops to the stirring solution of copper (II) chloride dihydrate $(0.005 \mathrm{~mol})$ dissolved in $20 \mathrm{~mL}$ of deionized water. The precipitation of the product was immediately formed. The reaction (Figure 1) continued with stirring for about an hour after which the precipitates formed were obtained by filtration under suction. Washing of the solid products was done with deionized water and these solids were dried in vacuo over silica gel. The synthesis, characterization and antimicrobial activity of this complex used for this study has been reported by Odola and Woods [31-33]. Standard stock solutions containing $1000 \mu \mathrm{g} \mathrm{mL}^{-1}$ analyte each were prepared in $1 \mathrm{~L}$ volumetric flask from nitrate salts of $\mathrm{Pb}, \mathrm{Cr}, \mathrm{Co}, \mathrm{Ni}$ and sulphate of $\mathrm{Mn}$. Diluted standard solutions were prepared from the stock standard solutions. For $\mathrm{pH}$ adjustment, each of the following buffer solutions was prepared in $500 \mathrm{~mL}$ volumetric flask and made up to the mark with de-ionized distilled water.

Preparation of buffer 2 solution: $3.8002 \mathrm{~g}$ of sodium di-hydrogen phosphate $\left(\mathrm{NaH}_{2} \mathrm{PO}_{4}\right)$ was dissolved in $9.0 \mathrm{ml}$ of $85 \%$ phosphoric acid $\left(\mathrm{H}_{3} \mathrm{PO}_{4}\right)$.

Preparation of buffer 3 solution: $13.8007 \mathrm{~g}$ of sodium di-hydrogen phosphate $\left(\mathrm{NaH}_{2} \mathrm{PO}_{4}\right)$ was dissolved in $0.60 \mathrm{~mL}$ of $85 \%$ phosphoric acid $\left(\mathrm{H}_{3} \mathrm{PO}_{4}\right)$.

Preparation of buffer 4 solution: $77.0003 \mathrm{~g}$ ammonium acetate $\left(\mathrm{CH}_{3} \mathrm{COONH}{ }_{4}\right)$ was dissolved in $413.0 \mathrm{~mL}$ acetic acid $\left(\mathrm{CH}_{3} \mathrm{COOH}\right)$.

Preparation of buffer 5 solution: $13.1008 \mathrm{~g}$ sodium di-hydrogen phosphate $\left(\mathrm{NaH}_{2} \mathrm{PO}_{4}\right)$ was mixed with $2.4002 \mathrm{~g}$ disodium hydrogen phosphate $\left(\mathrm{Na}_{2} \mathrm{HPO}_{4}\right)$.

Preparation of buffer 6 solution: $58.5003 \mathrm{~g}$ ammonium acetate $\left(\mathrm{CH}_{3} \mathrm{COONH}_{4}\right)$ and $2.5 \mathrm{~mL}$ acetic acid $\left(\mathrm{CH}_{3} \mathrm{COOH}\right)$ were added together.

Preparation of buffer 7 solution: $0.7005 \mathrm{~g}$ sodium borate $\left(\mathrm{Na}_{2} \mathrm{~B}_{4} \mathrm{O}_{7}\right)$ was mixed with $5.0 \mathrm{~mL} 1 \mathrm{M}$ hydrochloric acid $(\mathrm{HCl})$

Preparation of buffer 8 solution: $53.5200 \mathrm{~g}$ ammonium chloride $\left(\mathrm{NH}_{4} \mathrm{Cl}\right)$ was mixed with $4.0 \mathrm{~mL}$ ammonia $\left(\mathrm{NH}_{3}\right)$.

Preparation of buffer 9 solution: $500 \mathrm{~mL}$ of $0.1 \mathrm{M}$ ammonium chloride and $250 \mathrm{~mL}$ of $0.1 \mathrm{M}$ ammonia were mixed together.

Preparation of buffer 10 solution: $37.0100 \mathrm{~g}$ ammonium chloride and $285.0 \mathrm{~mL}$ ammonia were added together.

\section{General procedure for method development using a model} solution

The procedure of copper (II) methylbutyldithiocarbamate co-precipitation was optimized with model solutions prior to its application to real samples. Portions of $25 \mathrm{~mL}$ of an aqueous solution containing $20 \mu \mathrm{g}$ of $\mathrm{Pb}, 20 \mu \mathrm{g}$ of $\mathrm{Cr} ; 5 \mu \mathrm{g}$ of $\mathrm{Co}$ and $10 \mu \mathrm{g}$ of $\mathrm{Ni}$ and Mn were placed in centrifuge tubes separately. The adjustment of the $\mathrm{pH}$ of the solutions in the range of $\mathrm{pH} 2-10$ was done by the addition of $2.0 \mathrm{~mL}$ of various buffer solutions prepared. Then, $1.0 \mathrm{~mL}$ of 1,000 $\mathrm{mg} / \mathrm{L}$ of copper (II) as a carrier element and $1 \%(\mathrm{w} / \mathrm{v})$ methylbutyl dithiocarbamate were added to each solution. After 10 minutes, the solutions were centrifuged at $4000 \mathrm{rpm}$ for 30 minutes. The filtrates were decanted after centrifuging and the precipitates adhering to the tubes were dissolved with $1.0 \mathrm{~mL}$ of concentrated $\mathrm{HNO}_{3}$. The solutions were made up to $10 \mathrm{~mL}$ using de-ionized distilled water. The heavy metals in final solutions were determined by Atomic Absorption Spectrophotometry (AAS) (using Perkin Elmer AAnalyst 200).

\section{Optimization of operating condition}

Effect of pH: $\mathrm{pH}$ range of 2-10 was use during the investigation of the effect of $\mathrm{pH}$ on the quantitative recoveries of heavy metal ions on the copper (II) methylbutyldithiocarbamate. Various metal model solutions $(20 \mu \mathrm{g}$ of $\mathrm{Pb}, 20 \mu \mathrm{g}$ of $\mathrm{Cr} ; 5 \mu \mathrm{g}$ of $\mathrm{Co}$ and $10 \mu \mathrm{g}$ each of $\mathrm{Ni}$ and $\mathrm{Mn}$ ) were placed in centrifuge tubes separately. This was followed 
Citation: Ipeaiyeda AR, Asagunla OJ (2014) Co-Precipitation Procedure Using Copper (II) Methylbutyldithiocarbamate for Atomic Absorption Spectrophotometric Determination of Heavy Metals in Aqueous Standard Solutions and Environmental Samples. J Environ Anal Toxicol 4 : 257. doi: $10.4172 / 2161-0525.1000257$

by $1.0 \mathrm{~mL}$ of $1000 \mathrm{mgL}^{-1}$ of copper (II) as carrier element and $1.0 \mathrm{~mL}$ of $1 \%(\mathrm{w} / \mathrm{v})$ sodium methylbutyldithiocarbamate. $\mathrm{pH}$ of the solutions were adjusted by adding $2.0 \mathrm{~mL}$ of the appropriate buffer solutions. The solutions were centrifuged at $4000 \mathrm{rpm}$ for $30 \mathrm{~min}$ after $10 \mathrm{~min}$. The precipitate which remained on the centrifuge tubes were dissolved with $1.0 \mathrm{~mL}$ of concentrated $\mathrm{HNO}_{3}$. The solutions were made up to $10 \mathrm{~mL}$ mark using de-ionized distilled water before the metal concentrations were determined by Atomic Absorption Spectrophotometry (AAS) (Figure 2).

Effect of $\mathrm{Cu}^{2+}$ as carrier element: The effect of amount of $\mathrm{Cu}^{2+}$ as carrier element on the recoveries of metal ions was investigated. The various metal solutions $(20 \mu \mathrm{g}$ of $\mathrm{Pb}, 20 \mu \mathrm{g}$ of $\mathrm{Cr} ; 5 \mu \mathrm{g}$ of $\mathrm{Co}$ and 10 $\mu \mathrm{g}$ of $\mathrm{Ni}$ and $\mathrm{Mn}$ ) were placed in centrifuge tubes separately. Varying amounts of $\mathrm{Cu}$ solutions ranging from $0 \mathrm{mg}$ to $4.0 \mathrm{mg}$ of $1,000 \mathrm{mg} / \mathrm{L}$ solutions and $1.0 \mathrm{~mL}$ of $1 \%(\mathrm{w} / \mathrm{v})$ sodium methylbutyl dithiocarbamate were added to the various metal ions solutions. The $\mathrm{pH}$ of the solutions was adjusted to $\mathrm{pH} 9$. After $10 \mathrm{~min}$, the solutions were centrifuged and the precipitate which adhered on the centrifuge tubes were dissolved with concentrated $\mathrm{HNO}_{3}$. The heavy metals in the final solution were determined by AAS. The quantitative recoveries were obtained for all metals ions at the range of 1.0-3.0 $\mathrm{mg}$ of $\mathrm{Cu}^{2+}$ (Figure 3). All further works were carried out by addition of $1.0 \mathrm{mg}$ of $\mathrm{Cu}^{2+}$ as carrier element.

Effect of amount of methylbutyl dithiocarbamate: The effect of the amount of methylbutyldithiocarbamate on the quantitative co-precipitation of heavy metal ions was investigated in the range of $0.0-40.0 \mathrm{mg}$ of methylbutyl dithiocarbamate. $1.0 \mathrm{~mL}$ of $1,000 \mathrm{mg} / \mathrm{L}$ of copper (II) as a carrier element was added to aqueous solutions containing $20 \mu \mathrm{g}$ of $\mathrm{Pb}, 20 \mu \mathrm{g}$ of $\mathrm{Cr} ; 5 \mu \mathrm{g}$ of Co and $10 \mu \mathrm{g}$ of $\mathrm{Ni}$ and $\mathrm{Mn}$ ) placed in centrifuge tubes separately. Various volume $(0 \mathrm{~mL}, 1 \mathrm{~mL}, 2$ $\mathrm{mL}, 3 \mathrm{~mL}$ and $4 \mathrm{~mL}$ corresponding to $0 \mathrm{mg}, 10 \mathrm{mg}, 20 \mathrm{mg}, 30 \mathrm{mg}$ and $40 \mathrm{mg}$ respectively) of $1 \%(\mathrm{w} / \mathrm{v})$ of the methylbuthyldithiocarbamate were added to each of the metal ions solutions. An appropriate buffer solution was added to adjust the $\mathrm{pH}$ of the solutions to $\mathrm{pH}$ 9. The solutions were centrifuged after $10 \mathrm{~min}$ and the precipitate which

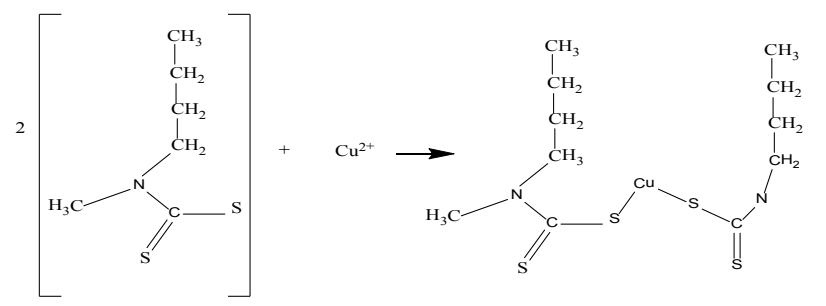

Figure 1: The equation for the formation of copper(II) methylbutyldithiocarbamate

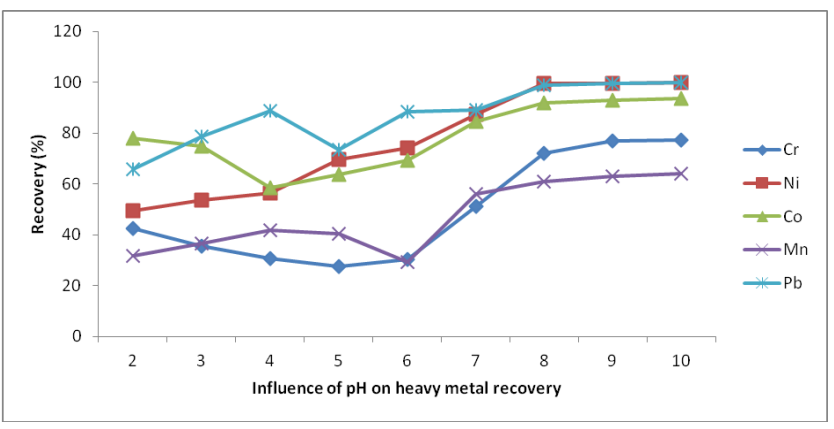

Figure 2: Effect of $\mathrm{pH}$ on heavy metals recovery in model solutions adhered to the centrifuge tubes were dissolved with concentrated $\mathrm{HNO}_{3}$. The solutions were made up to $10 \mathrm{~mL}$ using de-ionized distilled water. The heavy metals concentrations in the final solutions were determined by AAS. The optimum recoveries were obtained for all metals ions at the range of 10-40 mg of methylbutyldithiocarbamate (Figure 4). For all further works, $10.0 \mathrm{mg}$ of methylbutyldithiocarbamate was used.

Effect of sample volume on metal ions solutions: The effect of sample volume on the co-precipitation efficiency of metal ions was examined in the range of $10-500 \mathrm{~mL}$ to determine the volume applicable for the co-precipitation procedure for natural water samples and sediment samples. Solutions of metal concentrations of $\mathrm{Pb}, \mathrm{Cr}$, $\mathrm{Co}, \mathrm{Ni}$ and $\mathrm{Mn}$ were placed in centrifuge tubes separately and $1 \mathrm{~mL}$ of $1000 \mathrm{mgL}^{-1}$ of copper (II) as a carrier element (i.e $1 \mathrm{mg} \mathrm{Cu}{ }^{2+}$ ) was added to each solution. And $1 \mathrm{~mL}$ of $1 \%(\mathrm{w} / \mathrm{v})$ of the methylbuthyldithiocarbamate ligand was added. Then $\mathrm{pH}$ of the metal ions solutions were adjusted to $\mathrm{pH} 9$ by the addition of $2 \mathrm{~mL}$ of ammonia/ammonium buffer solution. The solutions were centrifuged at $4000 \mathrm{rpm}$ for 30 minutes after 10 minutes. After centrifuging, the filterate was decanted and the precipitate adhering to the tubes was dissolved with $1.0 \mathrm{~mL}$ of concentrated $\mathrm{HNO}_{3}$. The solutions were completed to $10 \mathrm{~mL}, 25 \mathrm{~mL}$, $50 \mathrm{~mL}, 100 \mathrm{~mL}, 250 \mathrm{~mL}$ and $500 \mathrm{~mL}$ in corresponding standard flasks using distilled water. Then the heavy metals in the final solutions were determined by Flame Atomic Absorption Spectrophotometry. The recoveries of heavy metal ions were found quantitative in the sample volume range of $10-100 \mathrm{~mL}$ (Figure 5) and were not quantitative as the volume increased to $500 \mathrm{~mL}$. Therefore the minimum volume of $10 \mathrm{~mL}$ was preferred for the co-precipitation procedure for river water and sediment samples.

Effect of interference ion: In order to assess the possible analytical applications of the procedure presented, the effect of some foreign ions which may interfere with the method or/and often accompany metal ions in various real samples was examined with the optimized conditions stated. For these studies, a fixed amount of metal ions was measured with different amounts of foreign ions (Table 1) and recommended procedure given was followed. The recoveries of analyte ions were generally higher than $80 \%$. The results revealed (Table 1) that reveal large numbers of ions used had no considerable effect on the determination of analyte ions.

\section{Application of co-precipitation method to real samples}

Description of sampling area and sampling design: The Coastal area of Ondo State, Nigeria, is one of such coasts that require regulation and monitoring. It is among the Oil belt region of Nigeria where Crude oil exploration is going on. It is equally located between the Lagos coast with very high population density and industrial activities and the Delta coast where there is high volume of on-going crude oil exploration. Ilaje communities are located in the southern part coastal area of Ondo State, the villages spread to the mangrove forest, closer to the Atlantic Ocean. The main occupation of the inhabitants is fishing; hence, a large fish market is located in the area that attracts buyers from all parts of the country. Oil exploration in these communities sometimes leads to pollutions of the water due to spillage. Ilaje communities are one of the Oil producing communities in the Niger Delta region of Nigeria. The sewage and other domestic waste from settlement around the coast are additional sources of pollution in the coasts.

River water and sediment were collected between August and October 2013. Water and sediment samples each were collected along River Ufara at Larada community in Igbokoda, Ondo State, where major oil exploration activities are on going. A portion of the river at 
Citation: Ipeaiyeda AR, Asagunla OJ (2014) Co-Precipitation Procedure Using Copper (II) Methylbutyldithiocarbamate for Atomic Absorption Spectrophotometric Determination of Heavy Metals in Aqueous Standard Solutions and Environmental Samples. J Environ Anal Toxicol 4: 257. doi: $10.4172 / 2161-0525.1000257$

Page 4 of 7

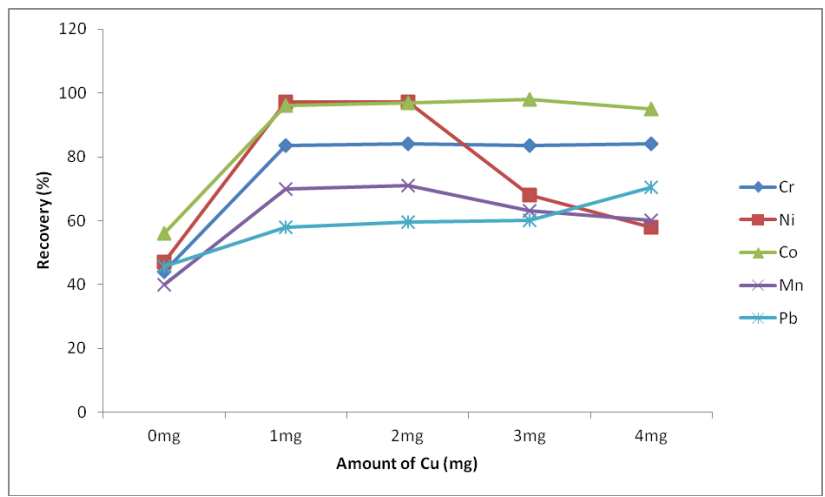

Figure 3: Effect of the amount of $\mathrm{Cu}^{2+}$ (as carrier element) in model solutions

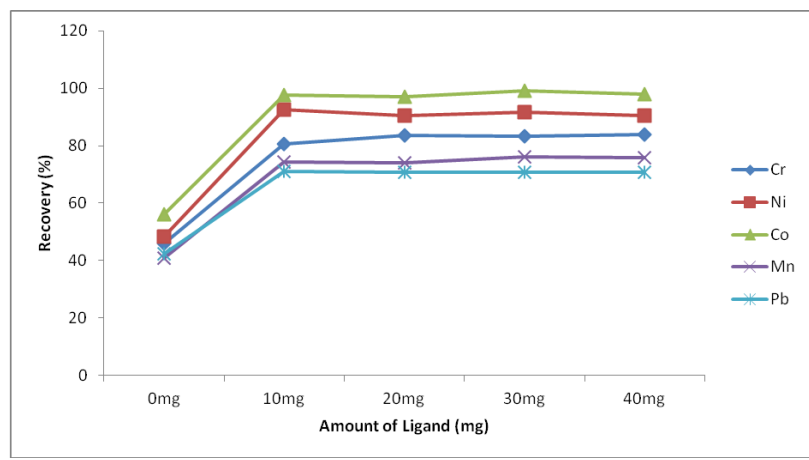

Figure 4: Effect of the amount of methylbuty-dithiocarbamate (MBDTC) on metal recovery in model solutions

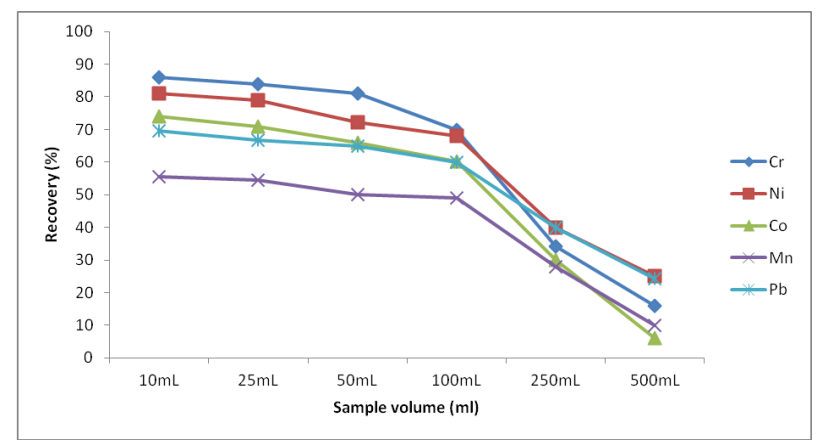

Figure 5: The effect of sample volume on metal recovery in model solutions

about $2 \mathrm{~km}$ far upstream was designated as control location where ten water and sediment samples each were equally collected. A total of eighty water and sediment samples were collected within the sampling periods.

Sampling, preservation and analysis of river water and sediment samples: An acid-cleaned polythene bottles were used to collect water samples which were acidified with $3 \mathrm{~mL}$ of $1.0 \mathrm{M}$ analar grade nitric acid per litre of sample. The samples were stored in an ice chest at the field and later stored at $4{ }^{\circ} \mathrm{C}$ in a refrigerator at the laboratory. Prior to metal analysis, the acidified water was neutralised and adjusted to $\mathrm{pH}$ 7. Portions $(200 \mathrm{~mL})$ of well mixed water samples were digested with 5 $\mathrm{mL}$ of concentrated nitric acid on a water bath and were concentrated to almost dryness. The solutions, after cooling, were filtered into 10
$\mathrm{mL}$ volumetric flask and made up to the mark with de-ionized distilled water.

Sediments collected with Van Veen type grab samplers were stored in polythene containers, air-dried in the laboratory, ground to fine powder and sieved through $0.55 \mathrm{~mm}$ screen. Known weights of the dry sieved sediment samples were digested with aqua regia which was a mixture of $\mathrm{HCl}-\mathrm{HNO}_{3}(3: 1)$ on a water bath for $2 \mathrm{~h}$. The mixtures were evaporated almost to dryness after the evolution of nitrogen (IV) oxide fumes had ceased. The resulting mixtures were then mixed with $5 \mathrm{~mL}$ aqua regia, filtered into $10 \mathrm{ml}$ volumetric flask and made up to the mark with de-ionized distilled water.

Optimized conditions for co-precipitation procedure were applied to the digested water and sediment samples. The final solutions were diluted to $10 \mathrm{~mL}$ in volumetric flask and the metal concentrations were determined by AAS.

\section{Validation of procedure and analytical performance}

In order to validate the accuracy of the method, replicate analysis of stream sediment standard reference material, ST-SD-4, was carried out for $\mathrm{Ni}$ (II), $\mathrm{Cr}$ (II), $\mathrm{Co}$ (II), Mn (II) and $\mathrm{Pb}$ (II) using co-precipitation procedure. ST-SD-4 was obtained from Canada Centre for Mineral and Energy Technology (CANMET, Canada). A known amount, 0.1 $\mathrm{g}$ of standard reference material for sediment was digested with aqua regia at room temperature in a water bath. The mixture was evaporated almost to dryness after the evolution of nitrogen (IV) oxide fumes had ceased. The resulting mixtures were then mixed with $5 \mathrm{~mL}$ aqua regia, filtered into $10 \mathrm{ml}$ volumetric flask and made up to the mark with de-ionized distilled water. Recovery test was also carried out on ten previously analysed water samples by spiking with various amounts of Ni (II), Cr (II), Co (II), Mn (II) and Pb (II) standard solutions. The subsequent procedures were the same as those described in section co-precipitation of the metals studied in model solution. The final solution was diluted to $10 \mathrm{~mL}$. Mean percentage recoveries of the metal ions were satisfactory. The limits of detection of the co-precipitation method for the determination of investigated metal ions were studied by applying optimum experimental conditions to ten $(n=10)$ blank solutions.

\section{Results and Discussion}

Quantitative recovery values ranging from $60.9 \%$ to $99.9 \%$ were obtained for $\mathrm{Pb}$ (II), Ni (II), Co (II), Cr (III) and $\mathrm{Mn}$ (II) in the $\mathrm{pH}$ range of 8-10. All subsequent works were performed at $\mathrm{pH} 9$ by adjusting with ammonia/ammonium chloride buffer (Figure 1). The optimum recoveries were obtained for all metal ions in the range of 1.0$3.0 \mathrm{mg}$ of $\mathrm{Cu}^{2+}$ due to the formation of dithiocarbamate precipitate. The recoveries of precipitate (40.0-52.9\%) were not quantitative without $\mathrm{Cu}^{2+}$ (Figure 2). Subsequent recoveries were carried out by the addition of $1.0 \mathrm{mg}$ of $\mathrm{Cu}^{2+}$ as carrier element with which the recovery was most quantitatively obtained. The quantitative recoveries of the metals were obtained in the range of 10.0-40.0 mg of methylbutyl dithiocarbamate. The recoveries of the metals in this range of amount of methylbutyl dithiocarbamate used were between $74.2 \%$ and $92.5 \%$ (Figure 3). For subsequent works, $10.0 \mathrm{mg}$ of methylbutyl dithiocarbamate was used. A pre-concentration factor of 10 for the metal ions was achieved when the final volume was $10 \mathrm{~mL}$ with the highest sample volume of 100 $\mathrm{mL}$ (Figure 4). The quantitative recoveries in this study arising from the effect of operating parameters for co-precipitation of metal ions with methybutylthiocarbamate were compared with other types of dithiocarbamates (Table 2). The optimum recoveries obtained in this 
Citation: Ipeaiyeda AR, Asagunla OJ (2014) Co-Precipitation Procedure Using Copper (II) Methylbutyldithiocarbamate for Atomic Absorption Spectrophotometric Determination of Heavy Metals in Aqueous Standard Solutions and Environmental Samples. J Environ Anal Toxicol 4 : 257. doi: 10.4172/2161-0525.1000257

Page 5 of 7

\begin{tabular}{|c|c|c|c|c|c|c|c|}
\hline \multirow[t]{2}{*}{ lons } & \multirow[t]{2}{*}{ Salt added } & \multirow[t]{2}{*}{ Concentration (ppm) } & \multicolumn{5}{|c|}{ Recovery (\%) } \\
\hline & & & $\mathrm{Mn}$ & $\mathrm{Cr}$ & $\mathrm{Ni}$ & $\mathrm{Pb}$ & Co \\
\hline $\mathrm{K}^{+}$ & $\mathrm{KCl}$ & 1000 & 95 & 103 & 84 & 95 & 92 \\
\hline $\mathrm{Cl}^{-}$ & $\mathrm{KCl}$ & 1000 & 90 & 100 & 101 & 101 & 93 \\
\hline $\mathrm{Al}^{3+}$ & $\mathrm{Al}_{2}\left(\mathrm{SO}_{4}\right)_{3}$ & 250 & 88 & 113 & 83 & 110 & 86 \\
\hline $\mathrm{Fe}^{3+}$ & $\mathrm{FeCl}_{3}$ & 250 & 82 & 98 & 91 & 102 & 91 \\
\hline $\mathrm{Zn}^{2+}$ & $\mathrm{ZnSO}_{4}$ & 1000 & 87 & 106 & 88 & 96 & 97 \\
\hline
\end{tabular}

Values of recovery are average of triplicate analysis

Table 1: The effect of interference ion on heavy metal recovery

\begin{tabular}{|c|c|c|c|c|c|c|c|c|c|}
\hline Technique & Analytes & Matrix(\% Recovery) & System & Eluent & PF & $\begin{array}{c}\text { Detection } \\
\text { limit }\left(\mu g L^{-1}\right)\end{array}$ & $\begin{array}{c}\text { R.S.D } \\
(\%)\end{array}$ & Optimum operating condition & Reference \\
\hline \multirow{4}{*}{ FAAS } & \multirow{4}{*}{$\begin{array}{l}\mathrm{Cu}, \mathrm{Fe}, \mathrm{Pb}, \mathrm{Mn}, \\
\mathrm{Zn}, \mathrm{Cd}, \mathrm{Ni}, \mathrm{Bi}, \mathrm{Cr}\end{array}$} & & \multirow{4}{*}{ Co-DEDTC } & \multirow{4}{*}{$1.0 \mathrm{~mL}$ conc. $\mathrm{HNO}_{3}$} & \multirow{4}{*}{225} & \multirow{4}{*}{$4-64$} & \multirow{4}{*}{$<7$} & $\mathrm{pH}:$ & \multirow{4}{*}[32]{} \\
\hline & & & & & & & & Amount of carrier element $(\mathrm{mg})$ : & \\
\hline & & & & & & & & Amount of chelating agent $(\mathrm{mg})$ : & \\
\hline & & & & & & & & Sample volume $(\mathrm{mL})$ & \\
\hline \multirow{4}{*}{ FAAS } & \multirow{4}{*}{$\begin{array}{c}\mathrm{Pb}, \mathrm{Cd}, \mathrm{Cr}, \mathrm{Ni} \\
\mathrm{Mn}\end{array}$} & \multirow{4}{*}{ Water(96 - 98) } & \multirow{4}{*}{ Cu- DBDTC } & \multirow{4}{*}{$0.5 \mathrm{~mL}$ conc. $\mathrm{HNO}_{3}$} & \multirow{4}{*}{50} & \multirow{4}{*}{$0.34-0.87$} & \multirow{4}{*}{$<10$} & $\begin{array}{c}\mathrm{pH}: \\
9\end{array}$ & \multirow{4}{*}{ [33] } \\
\hline & & & & & & & & Amount of carrier element $(\mathrm{mg}): \quad 1$ & \\
\hline & & & & & & & & Amount of chelating agent $(\mathrm{mg}): \quad 10$ & \\
\hline & & & & & & & & Sample volume $(\mathrm{mL})$ : & \\
\hline \multirow{4}{*}{ FAAS } & \multirow{4}{*}{$\mathrm{Cd}, \mathrm{Cu}, \mathrm{Pb}$} & \multirow{4}{*}{ Water( $88.6-103.5)$} & \multirow{4}{*}{$\begin{array}{l}\text { Bi(III)4- } \\
\text { MPDTC }\end{array}$} & \multirow{4}{*}{$1 \mathrm{~mL}$ conc. $\mathrm{HNO}_{3}$} & \multirow{4}{*}{200} & \multirow{4}{*}{$0.18-0.50$} & \multirow{4}{*}{$<10$} & $\mathrm{pH}: \quad 5$ & \multirow{4}{*}{ [26] } \\
\hline & & & & & & & & Amount of carrier element (mg): 4 & \\
\hline & & & & & & & & Amount of chelating agent $(\mathrm{mg}): 400$ & \\
\hline & & & & & & & & Sample volume $(\mathrm{mL}): \quad 250$ & \\
\hline \multirow{4}{*}{ FAAS } & \multirow{4}{*}{$\begin{array}{l}\mathrm{Ni}, \mathrm{Cr}, \mathrm{Mn}, \mathrm{Pb}, \\
\mathrm{Zn}\end{array}$} & \multirow{4}{*}{$\begin{array}{c}\text { Water }(96.8-100) \\
\text { Sediment (97.3- } \\
99.2)\end{array}$} & \multirow{4}{*}{ Cu-cHMDTC } & \multirow{4}{*}{$0.5 \mathrm{~mL}$ conc. $\mathrm{HNO}_{3}$} & \multirow{4}{*}{10} & \multirow{4}{*}{$0.003-0.10$} & \multirow{4}{*}{$<17$} & $\mathrm{pH}:$ & \\
\hline & & & & & & & & Amount of carrier element $(\mathrm{mg}): 1$ & [28] \\
\hline & & & & & & & & Amount of chelating agent(mg): 10 & [28] \\
\hline & & & & & & & & Sample volume $(\mathrm{mL})$ : & \\
\hline & $\mathrm{Ni}$ & $\begin{array}{c}\text { Water }(89.5 \pm 1.3) \\
\text { Sediment }(90.2 \\
\pm 0.3)\end{array}$ & & & & & & $\mathrm{pH}: \quad 9$ & \\
\hline EAAS & $\mathrm{Cr}$ & $\begin{array}{c}\text { Water }(93.2 \pm 2.1) \\
\text { Sediment }(87.2 \\
\pm 1.1)\end{array}$ & & & & & & Amount of carrier element (mg): 1 & \\
\hline FAAS & Co & $\begin{array}{c}\text { Water }(92.1 \pm 2.4) \\
\text { Sediment }(89.0 \\
\pm 0.5)\end{array}$ & CU-IVIBDIC & $1.0 \mathrm{~mL}$ conc. $\mathrm{HINO}_{3}$ & 10 & $0.003-0.006$ & $<5$ & Amount of chelating agent(mg): 10 & Inis study \\
\hline & $\mathrm{Mn}$ & $\begin{array}{l}\text { Water }(89.7 \pm 0.5) \\
\text { Sediment }(92.7 \\
\pm 0.4)\end{array}$ & & & & & & Sample volume $(\mathrm{mL})$ : & \\
\hline
\end{tabular}

PF - preconcentration factor, R.S.D - Relative Standard Deviation; DEDTC - diethyldithiocarbamate; DBDTC - dibenzyldithiocarbamate; MPDTC methylpiperidinedithiocarbamate; MBDTC - methylbutyldithiocarbamate FAAS - Flame atomic absorption spectrometry; cHMDTC - cyclohexylmethyldithiocarbamate

Table 2: Comparison of this study with data from some previous studies on preconcentration-separation of heavy metal ions.

study were about the recoveries reported for other dithiocarbamates.

The detection limits for the investigated metal ions based on three times standard deviations of the blank were Ni: $0.003 \mathrm{mg} / \mathrm{L}, \mathrm{Cr}: 0.005$ $\mathrm{mg} / \mathrm{L}, \mathrm{Pb}: 0.006 \mathrm{mg} / \mathrm{L}, \mathrm{Mn}: 0.005 \mathrm{mg} / \mathrm{L}$ and Co: $0.005 \mathrm{mg} / \mathrm{L}$. The comparative data from co-precipitation studies were given in Table 2. Percentage recoveries obtained were still good and satisfactory in spite of the low pre-concentration factor achieved in this study. The results of replicate analysis of reference standard material (ST-SD4) from the co-precipitation were compared with the certified values using a t-test at $95 \%$ confidence level. The observed values and certified values for $\mathrm{Ni}, \mathrm{Cr}, \mathrm{Co}, \mathrm{Mn}$ and $\mathrm{Pb}$ were not significantly different (Table 3). Thus, the accuracy of the procedure and the absence of matrix effects are confirmed. This implies that the proposed co-precipitation method can possibly be applied for the preconcentration of heavy metal ions in real environmental samples.

Table 4 shows the application of co-precipitation procedure for the determination of $\mathrm{Ni}, \mathrm{Pb}, \mathrm{Cr}, \mathrm{Co}$ and $\mathrm{Mn}$ in river water and sediment samples. The metal ions in the samples were equally determined by atomic absorption spectrophotometric technique without coprecipitation procedure. The results obtained without co-precipitation were generally lower than for co-precipitation as revealed in Table 4. It is somehow difficult to generalize the accuracy and precision of atomic absorption spectrophotometric technique with co-precipitation procedure over the spectrometric technique without co-precipitation procedure. From Table 4, it is apparent that there are certain systematic errors associated with the two procedures. The matrices of sample and chemical compositions of the final soluble complex of metal ions with the precipitating agent are possible sources of error. A moderately soluble complex with heavy metal ions is expected to be formed with either organic or inorganic precipitating agent. This probably accounted for high average levels of $\mathrm{Ni}, \mathrm{Pb}, \mathrm{Cr}$, $\mathrm{Co}$ and $\mathrm{Mn}$ in this study by atomic absorption spectrophotometric determination preceded by coprecipitation procedure. The precision of results from the two different treatment procedures for heavy metals determination in water and sediment samples was considered using one way analysis of variance 
Citation: Ipeaiyeda AR, Asagunla OJ (2014) Co-Precipitation Procedure Using Copper (II) Methylbutyldithiocarbamate for Atomic Absorption Spectrophotometric Determination of Heavy Metals in Aqueous Standard Solutions and Environmental Samples. J Environ Anal Toxicol 4 : 257. doi: 10.4172/2161-0525.1000257

Page 6 of 7

\begin{tabular}{|c|c|c|c|}
\hline \multirow{2}{*}{ Metals } & \multicolumn{2}{|c|}{ Observed concentration } & Certified value \\
\hline & Sediment without Cu- MBDTC & Sediment with Cu- MBDTC & 23 \\
\hline Nickel $(\mathrm{Ni})$ & $17.2 \pm 0.41$ & $19.8 \pm 0.7$ & 30 \\
\hline Chromium (Cr) & $24.7 \pm 0.1$ & $27.9 \pm 0.5$ & 11 \\
\hline Cobalt (Co) & $9.07 \pm 0.34$ & $14.5 \pm 0.21$ & 1200 \\
\hline Manganese $(\mathrm{Mn})$ & $917 \pm 4$ & $981 \pm 11$ & 13 \\
\hline Lead $(\mathrm{Pb})$ & $11.3 \pm 0.5$ & $12.2 \pm 1.3$ & \\
\hline
\end{tabular}

Table 3: Observed concentrations $(\mu \mathrm{g} / \mathrm{g})$ of metals in standard reference material (ST-SD-4) and certified values $(n=5)$

\begin{tabular}{|c|c|c|c|c|}
\hline Metals & \multicolumn{2}{|c|}{ Water } & \multicolumn{2}{c|}{ Sediment } \\
\hline & Without Cu-MBDTC & With Cu-MBDTC & Without Cu-MBDTC & With Cu-MBDTC \\
\hline $\mathrm{Ni}(\mathrm{II})$ - sample & $0.13 \pm 0.11$ & $11.7 \pm 5.5$ & $9.3 \pm 1.1$ & $13.2 \pm 1.1$ \\
\hline $\mathrm{Ni}(\mathrm{II})$ - control & $0.07 \pm 0.01$ & $8.10 \pm 0.14$ & $7.20 \pm 0.50$ & $1.20 \pm 0.14$ \\
\hline $\mathrm{Cr}(\mathrm{III})$ - sample & $0.17 \pm 0.08$ & $6.06 \pm 0.80$ & $15.9 \pm 1.7$ & $19.5 \pm 0.9$ \\
\hline $\mathrm{Cr}(\mathrm{III})$ - control & $0.06 \pm 0.01$ & $4.20 \pm 0.14$ & $10.8 \pm 1.2$ & $13.1 \pm 1.2$ \\
\hline $\mathrm{Mn}(\mathrm{II})$ - sample & $0.28 \pm 0.05$ & $18.7 \pm 4.2$ & $47.1 \pm 12.3$ & $63.4 \pm 18.2$ \\
\hline $\mathrm{Mn}(\mathrm{II})$ - control & $0.20 \pm 0.02$ & $10.8 \pm 0.9$ & $18.9 \pm 1.8$ & $46.5 \pm 2.6$ \\
\hline $\mathrm{Pb}(\mathrm{II})$ - sample & $0.10 \pm 0.02$ & $7.8 \pm 1.5$ & $14.7 \pm 1.5$ & $21.9 \pm 3.2$ \\
\hline $\mathrm{Pb}(\mathrm{II})$ - control & $0.05 \pm 0.01$ & $4.70 \pm 0.90$ & $10.9 \pm 0.9$ & $14.3 \pm 3.1$ \\
\hline $\mathrm{Co}(\mathrm{II})$ - sample & $0.06 \pm 0.02$ & $1.52 \pm 0.11$ & $3.72 \pm 0.58$ & $5.6 \pm 1.3$ \\
\hline $\mathrm{Co}(\mathrm{II})$ - control & $0.01 \pm 0.00$ & $1.20 \pm 0.00$ & $2.65 \pm 0.35$ & $4.55 \pm 0.49$ \\
\hline
\end{tabular}

Table 4: Average metal ions concentrations (ppm) in water and sediment before and after co-precipitation with copper(II) - methylbutyl dithiocarbamate (Cu- MBDTC)

\begin{tabular}{|c|c|c|c|c|}
\hline \multirow[t]{2}{*}{ Metals } & \multicolumn{2}{|r|}{ Water } & \multicolumn{2}{|c|}{ Sediment } \\
\hline & p-value & Significant difference at level $p=0.05$ & $p$-value & $\begin{array}{l}\text { Significant difference at level } \\
\qquad p=0.05\end{array}$ \\
\hline $\mathrm{Ni}(\mathrm{II})$ - sample & 0.001600 & Yes & 0.022628 & Yes \\
\hline $\mathrm{Ni}(\mathrm{II})$ - control & 0.000155 & Yes & 0.002491 & Yes \\
\hline $\mathrm{Cr}(\mathrm{III})$ - sample & 0.000000232 & Yes & 0.002889 & Yes \\
\hline $\mathrm{Cr}(\mathrm{III})-$ control & 0.000583 & Yes & 0.195824 & No \\
\hline Mn(II)- sample & 0.00000976 & Yes & 0.135646 & No \\
\hline $\mathrm{Mn}(\mathrm{II})-$ control & 0.003188 & Yes & 0.006223 & Yes \\
\hline $\mathrm{Pb}(\mathrm{II})$ - sample & 0.00000281 & Yes & 0.001602 & Yes \\
\hline $\mathrm{Pb}(\mathrm{II})$ - control & 0.016249 & Yes & 0.274458 & No \\
\hline Co(II)- sample & 0.000000014 & Yes & 0.015519 & Yes \\
\hline $\mathrm{Co}(\mathrm{II})-$ control & - & No & 0.047616 & No \\
\hline
\end{tabular}

Table 5: Statistical analysis for the comparison of treatment technique without and with co-precipitation procedure for heavy metals determination from water and sediment samples

(Table 5). There was significant difference between the precisions of the two procedures. As much as precision always accompany accuracy, the output of this statistical method does not suggest hasty judgment that atomic absorption spectrophotometric determination of heavy metals with co-precipitation procedure is more accurate than without co-precipitation.

\section{Conclusion}

The application of atomic absorption spectrophotometric method preceeded by co-precipitation procedure for the determination of $\mathrm{Ni}$ (II), $\mathrm{Cr}$ (II), Mn (II), Pb (II) and Co (II) from aqueous solution using copper (II) methylbutyldithiocarbamate was reported for the first time in this study. The procedure was successfully applied to water and sediment samples. This procedure was equally validated with reference material and the accuracy was satisfactory.

\section{Acknowledgements}

Special thanks go to J. A. Odola of Inorganic Unit of department of Chemistry, University of Ibadan for his assistance over the synthesis of this complex.

\section{References}

1. Grabarczyk M, Korolczuk M (2010) Development of a simple and fast voltammetric procedure for determination of trace quantity of $\mathrm{Se}(\mathrm{IV})$ in natural lake and river water samples. J Hazard Mater 175: 1007-1013.

2. Afkhami A, Saber-Tehrani M, Bagheri H, Madrakian T (2011) Flame atomic absorption spectrometric determination of trace amounts of $\mathrm{Pb}(\mathrm{II})$ and $\mathrm{Cr}(\mathrm{III})$ in biological, food and environmental samples after preconcentration by modified nano-alumina. Microchimica Acta 172: 125-136.

3. Dickman MD, Leung KM (1998) Mercury and organochlorine exposure from fish consumption in Hong Kong. Chemosphere 37: 991-1015.

4. Mahaffey KR (2000) Recent advances in recognition of low-level methylmercury poisoning. Curr Opin Neurol 13: 699-707.

5. Guallar E, Sanz-Gallardo MI, van't Veer P, Bode P, Aro A, et al. (2002) Mercury, fish oils, and the risk of myocardial infarction. N Engl J Med 347: 1747-1754.

6. Hightower JM, Moore D (2003) Mercury levels in high-end consumers of fish Environ Health Perspect 111: 604-608.

7. Esrey SA, Potash JB, Roberts L, Shiff C (1991) Effects of improved water supply and sanitation on ascariasis, diarrhoea, dracunculiasis, hookworm infection, schistosomiasis, and trachoma. Bull World Health Organ 69: 609-621.

8. Galadima A, Garba ZN, Leke L, Almustapha MN, Adam IK (2011) Domestic Water Pollution among Local Communities in Nigeria - Causes and Consequences. European Journal of Scientific Research 52: 592-603.

9. Mucha AP, Vasconcelos MTSD, Bordalo AA (2003) Macrobenthic community in the Douro Estuary: relations with trace metals and natural sediment characteristics. Environmental Pollution 121: 169-180. 
Citation: Ipeaiyeda AR, Asagunla OJ (2014) Co-Precipitation Procedure Using Copper (II) Methylbutyldithiocarbamate for Atomic Absorption Spectrophotometric Determination of Heavy Metals in Aqueous Standard Solutions and Environmental Samples. J Environ Anal Toxicol 4 : 257. doi: 10.4172/2161-0525.1000257

10. Pekey $H$ (2006) The distribution and sources of heavy metals in Izmit Bay surface sediments affected by a polluted stream. Mar Pollut Bull 52: 1197-1208.

11. Okay OS, Tolun L, Telli-Karakoç F, Tüfekçi V, Tüfekçi H, et al. (2001) Izmit Bay (Turkey) ecosystem after Marmara earthquake and subsequent refinery fire: the long-term data. Mar Pollut Bull 42: 361-369.

12. Mohan D, Pittman CU Jr (2007) Arsenic removal from water/wastewater using adsorbent - a critical review. Journal of Hazardous Materials 142: 1-53.

13. Tokunga TK, Pickering IJ, Gordon E, Grown GE Jr (1996) Selenium transformation in ponded sediments. Soil Science Society of America Journal 60: 781-790

14. Markiewicz-Patkowska J, Hursthouse A, Przybyla-Kij H (2005) The interaction of heavy metals with urban soils: sorption behaviour of $\mathrm{Cd}, \mathrm{Cu}, \mathrm{Cr}, \mathrm{Pb}$ and $\mathrm{Zn}$ with a typical mixed brownfield deposit. Environ Int 31: 513-521.

15. Alamayehu T (2001) The impact of uncontrolled waste disposal on surface water quality of Addis Ababa. Ethiopian Journal of Science 24: 93-104.

16. Chirenje T, Ma LQ, Reeves M, Szulczewski K (2004) Lead distribution in near surface soils of two Florida cities: Gainesville and Miami. Geoderma 119: 113120.

17. Alamiyehu T (2006) Heavy metal concentration in the urban environmental of Addis Ababa, Ethiopia. Soil and Sediment Contamination 15: 591-602.

18. Reza R, Singh G (2010) Heavy metal contamination and its indexing approach for river water. International Journal of Environmental Science and Technology 7: 785-792.

19. Rubio R, Sahuquillo A, Rauret G, Quevauviller Ph (1992) Determination of chromium in environmental and biological samples by atomic absorption spectroscopy: a review. International Journal of Environmental Analytical Chemistry 47: 99-128.

20. Citak D, Tuzen M Soylak M (2009) Simultaneous coprecipitation of lead, copper, cadmium, iron and nickel in food samples with Zirconium (IV) hydroxide prior to their Flame Atomic Absorption Spectrometric determination. Journal of Food and Chemical Toxicology 47: 2302-2307.

21. Dolak I, Tegin I, Guzel R, Ziyadanogullari R (2009) Synthesis and preconcentration of Amberlite XAD-4 resin modified by dithioethylenediamine. Asian Journal of Chemistry 21: 165-175.

22. Jamshidi R, Afzali Z, Afzali K (2009) Modified natural zeolites as sorbent for for separation and pre-concentration of traces amount of metal ions. Asian Journal of Chemistry 21: 3381- 3384
23. Pérez-Quintanilla D, Sanchez A, del Hierro I, Fajardo M, Sierra I (2009) Solid phase extraction of $\mathrm{Pb}$ (II) in water samples using a new hybrid inorganicorganic mesoporous silica prior to its determination by FAAS. Microchimica Acta 165: 291-298.

24. Prasad K, Gopikrishna P, Kala R, Prasada-Rao T, Naidu GRK (2006) Solid phase extraction vis-'a-vis coprecipitation preconcentration of cadmium and lead from soils onto 5,7-dibromoquinoline-8-ol embedded benzophenone and determination by FAAS. Talanta 69: 938-945.

25. Chen H, Jin J, Wang Y (1997) Flow injection on-line coprecipitationpreconcentration system using copper (II) diethyldithiocarbamate as carrier for flame atomic absorption spectrometric determination of cadmium, lead and nickel in environmental samples. Analytica Chimica Acta 353: 181-188.

26. Efendioglu A, Yagan M, Bat B (2007) Bi (III)4-methylpiperidinedithiocarbamate coprecipitation procedure for separation-pre-concentration of trace metal ions in water samples by flame atomic absorption spectrometric determination. Journal of Hazardous Materials 149: 160-165.

27. Baysal A, Akman S, Calisir F (2008) A novel slurry sampling analysis of lead in different water samples by electrothermal atomic absorption spectrometry after coprecipitated with cobalt/pyrrolidine dithiocarbamate complex. J Hazard Mater 158: 454-459.

28. Ipeaiyeda AR, Odola $\mathrm{AJ}$ (2012) Co-precipitation of $\mathrm{Ni}, \mathrm{Cr}, \mathrm{Mn}, \mathrm{Pb}$ and $\mathrm{Zn}$ in industrial wastewater and sediment samples with copper(II) cyclohexylmethyldithiocarbamate for their flame atomic absorption spectrometric determination. Water Sci Technol 66: 105-112.

29. Elci L, Soylak M, Ozcan B (2003) Determination of total chromium by flame atomic absorption spectrometric determination. Analytical Letter 36: 987-998.

30. Minami T, Sohrin Y, Ueda J (2005) Determination of chromium, copper and lead in river water by graphite-furnace atomic absorption spectrometry after coprecipitation with terbium hydroxide. Anal Sci 21: 1519-1521.

31. Odola, AJ, Woods JAO (2012) Preparation, physico-chemical characterization and in vitro antifungal activity studies of copper (II) complexes of N,Ndiakyldithiocarbamates. Journal of Science Research 11: 44-50.

32. EIÃßi L, Sahin U, OztaÄŸ S (1997) Determination of trace amounts of some metals in samples with high salt content by atomic absorption spectrometry after cobalt-diethyldithiocarbamate coprecipitation. Talanta 44: 1017-1023.

33. Tuzen M, Soylak M (2009) Multi-element coprecipitation for separation and enrichment of heavy metal ions for their flame atomic absorption spectrometric determinations. J Hazard Mater 162: 724-729. 